PRZEGLĄD NAUK HISTORYCZNYCH 2016, R. XV, NR 1

http://dx.doi.org/10.18778/1644-857X.15.01.07

IHOR LYLO

(Uniwersytet Iwana Franki we Lwowie)

\title{
Miejsce Greków w kulturze materialnej Rzeczypospolitej w XVI-XVII wieku
}

W

e współczesnej historiografii odpowiedzi na pytania o obecność przedmiotów kultury materialnej napływajaccych do Europy Zachodniej w XVI-XVII w. z terenów wschodniej części Morza Śródziemnego są dość znane ${ }^{1}$. O wiele skromniejsze są wyniki badań, które dotyczą obszarów Europy Wschodniej i Środkowej².

${ }^{1}$ A. Battistelli, La republica di Venezia, Venezia 1897; H. Krets chmayr, Geschichte von Venedig, Bd. I-II, Gotha 1920; A.N. Kube, Veneceanskoje steklo, Petrograd 1923; L. Beltrami, Storia della popolazione di Venezia, Cedam 1950; R. Cessi, Politica ed economica di Venezia nel Trecento, Roma 1952; id e m, La republica di Venezia e il problema Adriatico, Napoli 1953; P.S. Leicht, Le colonie veneziane, "Rivista di storia del diritio italiano” 1953, vol. XXV, s. 35-39; G. Luzzato, Studi di storia economica veneziana, Padova 1954; B. Dudan, Il dominio veneziano di Levante, Bolonia 1938; A. Bailly, La république di Venize, Paris 1946; R. Grousset, L'empire de Levant, Paris 1946; N. Sokolov, Obrazovanije Venecianskoj kolonialnoj imperiji, Saratov 1963; F. D o n a ve r, La storia della repubblica di Genova, Genova 1975; G. Benvenuti, Storia della repubblica di Genova, Milano 1977; J.J. Norwich, A history of Venice, London 1982; C. Costantini, La repubblica di Genova, Torino 1988; S. Karpov, Putiami srednevekovych morechodov, Moskva 1994; S. Blyzniuk, Famagusta $v 15$ w., „Priczegnomorje v srednije veka" [Sankt-Petersburg] 2000, t. IV, s. 219-295; idem, Migracija veneceancov na Kipr v XIII-XV vv., "Rosija i Germanija” 2012, nr 2, s. 12-16; S.A. E p s te in, Genoa and the Genoese, 956-1528, London 2002; F. B rodel, Sredizemnoje more $i$ sredizemnomorskij mir $v$ epohu Filipa II, Moskva 2002; K.T. Ballis on, Genoa and the Sea: Policy and Power in an Early Modern Maritime Republic, Washington 2005; L. Voj tovy c h, Formuvannia krymskotatarskoho narodu. Vstup do etnohenezu, Bila Cerkva 2009, s. 150-157.

${ }^{2}$ A. Wy czań s ki, Polska-Rzecza Pospolita Szlachecka 1454-1764, Warszawa 1965; V. Gilles, Marchands ottomans en Pologne-Lituanie et en Moscovie sous le 
Od czasów wczesnego średniowiecza za pośrednictwem kupców z Halicza i Przemyśla, a później Lwowa, Brodów, Lublina, Kamieńca Podolskiego przedmioty codziennego użytku i luksusu ze Wschodu napływały na rynki lokalne. Stałe zainteresowanie miejscowych odbiorców posiadaniem tych przedmiotów zmieniało ich gusty i wpływało, w różny sposób, na układy społeczne i obyczajowe.

Jakie były potrzeby i wymagania w ówczesnej Europie Wschodniej? Jak wielki wpływ miały przywożone towary na odbiór świata zewnętrznego przez okolicznych mieszkańców? Jakie miejsce i udział w tym rynku mieli Grecy jako kupcy i wędrowcy licznie napływający na tereny Europy Wschodniej od drugiej połowy XVI w.? Oto pytania, na które szukamy odpowiedzi. Szczególnie miejsce Greków w ówczesnym społeczeństwie miast wschodniego pogranicza Rzeczypospolitej jest głównym tematem tej rozprawy.

Od czasów bliskich kontaktów Rusi Kijowskiej z Bizancjum towary ze Wschodu trafiały na tereny polskie słynnym „szlakiem od Waregów do Greków”, a po jego upadku - starym „szlakiem bursztynowym" znad Morza Czarnego do Bałtyku i Dniestru, dalej rzekami Sanem i Bugiem Zachodnim oraz Wisłą. Ta droga krzyżowała się z Via Regia (Kijów - Halicz [od XIII w. - Lwów] - Przemyśl, Kraków, Praga, Regensburg). $Z$ tego szlaku korzystano nawet po upadku księstwa Halicko-Wołyńskiego, aż do końca XIV-XV w. ${ }^{3}$

règne de Soliman le Magnifique, „Cahiers du monde russe: Russie, Empire russe, Union soviétique, États indépendants" 1994, vol. XXXV, no. 4, Octobre-Décembre, s. 713-738; M. Małow is t, Wschód a Zachód Europy w XIII-XVI wieku. Konfrontacje struktur społeczno-gospodarczych, Warszawa 1973; H. Sa m s on owicz, Miejsce Polski $w$ Europie, Warszawa 1995; id e m, Złota jesień polskiego średniowiecza, Poznań 2001; E. Nadel-Golobic, Armenians and Jews in Medieval Lvov: Their role in Orient trade, "Cahiers de Monde Russe et Sovietique" [Paris-HagueNew York] 1979, vol. XX, nos. 3-4, s. 345-388; C.N. A petrei, Greek merchants in Romanian Principalities in the $16^{\text {th }}$ c.: The case of Nicolaos Domesticos Nevridis, „ISTROS” [Brâila] 2011, vol. XVII, s. 95-121; ide m, Rethinking the connections of a sixteenth century family. The Korniakt Merchants and Moldavia from 1540 to 1570, „ISTROS” [Brâila] 2014, vol. XX, s. 565-583; ide m, The Transit of Cretan wine in $16^{\text {th }}$ Century Moldavia. The European Context and Quantitative Assessments, "Transylvanian Review” 2013, vol. XXII, Supplement, No. 2 (Economic and Social Evolutions at the Crossroads of the World-System. Eastern and Central Europe from the Early Modern Age to the Twentieth Century), s. 193-203.

${ }^{3}$ L. Vojtovych, Torhivlia i torhovelni szlahu, [w:] Istorija ukrainskoji kultury, t. II (Ukrainska kultura XIII - persza polovyna XVII s.), Kyiv 2001, s. 81-93; id e m, Lev Danylovycz, kniaz halycko-volynskyj (bl. 1225 - bl. 1301), Lviv 2014, s. 69-71, $135,163-169$. 
Przynależność tych ziem do ówczesnego państwa polskiego wzmocniło pozycje miast na południowo-wschodniej granicy, m.in. na skutek przywileju nadanego 11 listopada 1380 r. przez króla Węgier, Polski, Galicji i Lodomerii - Ludwika Andegaweńskiego ${ }^{4}$, potwierdzonego przez królową Jadwige 8 marca 1387 r. ${ }^{5}$ oraz króla Władysława Jagiełłę 15 marca 1403 r. ${ }^{6} \mathrm{Na}$ pierwszym miejscu w wymianie towarów między Wschodem a Zachodem był Lwów. Orientalne towary przywożone na ziemie polskie, począwszy od lat trzydziestych XVI w., to przede wszystkim przedmioty luksusowe, odzież, broń i żywność. Miało to związek ze zmianami gospodarczymi w ówczesnej Europie.

Tureckie podboje we wschodniej części Morza Śródziemnego przez pewien czas pozbawiły europejskie społeczeństwa dostępu do stosunkowo taniego zboża i bydła. Luka ta jednak szybko została wypełniona. Rzeczpospolita organizowała potężny handel tymi artykułami przez Gdańsk i Bałtyk, a także starożytna Via Regia. Zajmując dawne ziemie Księstwa Halicko-Wołyńskiego, Polska odziedziczyła $z$ nimi handel na rzece Dniestr, a od momentu, kiedy Mołdawia i Wołoszczyzna zostały wasalami osmańskimi, zyskała również dostęp do granicy tureckiej, co ułatwiło kontakty kupcom po obu stronach ${ }^{7}$. Od tej chwili ich podróż stała się bardziej bezpieczna, co jednak nie wykluczało prób pobierania haraczu przez miejscowych. Ale ten przestępczy proceder można było na różne sposoby zwalczać8.

Wielkie odkrycia geograficzne przyczyniły się m.in. do napływu z Ameryki do Europy wielkiej ilości tanich pieniędzy. Złoto straciło na wartości i przyczyniło się do kryzysu w gospodarce rolnej takich krajów, jak Hiszpania czy Portugalia9 ${ }^{9}$ W tym okresie wzrosła liczba

${ }^{4}$ Archiwum Państwowe w Krakowie, Dyplomy pergaminowe, nr 70; Pryvileji mista Lvova (XIV-XVIII s.), uporiad M. Kapral, Lviv 1998, s. 44-45.

${ }^{5}$ Centralne Państwowe Archiwum Historyczne Ukrainy we Lwowie [dalej: CPAHL], Fond. 52, Op. 2, Spr. 1153, s. 181; Pryvileji mista Lvova..., s. 46-47.

${ }^{6}$ CPAHL, Fond. 52, Op. 2, Spr. 613, s. 32; Pryvileji mista Lvova..., s. 58-60.

${ }^{7}$ H. In aldžy k, Osmańska imperija. Klasyczna doba 1300-1600, Kyiv 1998, s. 147.

${ }^{8}$ Interesujaca wydaje się historia niejakiego Jakuba Chochorowskiego, który z pomoca miejscowych Żydów próbował rabować greckich kupców podążających do Lwowa $z$ transportem win. W położonej ok. $40 \mathrm{~km}$ od Lwowa miejscowości Bóbrka zorganizował własna „komorę celna”. Gdy jednak kupcy stanowczo odmawiali płacenia cła, prosił ich o chociażby degustacje win, CPAHL, Fond. 52, Op. 2, Spr. 21, s. 45.

${ }^{9}$ R. Rybars ki, Handel i polityka handlowa Polski $w$ XVI stuleciu, t. II, Poznań 1929, s. 42. 
mieszkańców miast w Europie Zachodniej. Przyśpieszyły tam nowe procesy ekonomiczne, które doprowadziły do wzrostu cen żywności. Tak zwany przewrót cen okazał się bardzo korzystny dla Polski. Nastąpił wzrost eksportu zboża, które mimo względnie niskiej ceny skupu wciąż pozostawało na poziomie konkurencyjnym. Działo się to dzięki temu, że na terenie ówczesnych ziem ukraińskich szlachta czerpała wysokie zyski, łącząc sprzyjające warunki geograficzno-klimatyczne $z$ prawie niewolniczą praca miejscowych chłopów ${ }^{10}$. Dalsze zainteresowanie zwiększeniem wydajności $z$ roli zmusiło właścicieli ziemskich do wprowadzenia form zarządzania na wzór gospodarstwa folwarcznego ${ }^{11}$. Gromadząc coraz większe środki finansowe, magnaci chętnie wydawali je na rozrywki i różnego rodzaju luksusy. Kupcy wschodni, w tym Grecy, aktywnie korzystali $z$ tej sytuacji. Pośrednikami w tym handlu byli mieszkańcy miast Europy Środkowej i Wschodniej ${ }^{12}$.

Zainteresowanie wysokiej jakości ubraniami, uprzężą dla koni, bronia, dywanami, dobrym jedzeniem rosło tak szybko, że niekiedy przybierało wręcz groteskową formę. W niektórych majątkach szlacheckich można było spotkać specjalne budowle zwane tatarniami. W posiadłości Jerzego Kalinowskiego w Bukoczowcach przebywali orientalni jeńcy i więźniowie, wśród których wymienione były "Greczynki"13.

Na dworze księcia Adama Czartoryskiego goście mogli zobaczyć sługę Jana, który specjalnie na ich wizytę przebierany był za Turka lub Araba, a sługa Gabriel spacerował między wyborną publicznościa jak egzotyczny „Hadzi Girej”, ubrany w kolorowe orientalne szaty. W Puławach, w pałacu wspomnianego księcia, cieszyła się popularnościa kawiarnia prowadzona przez Greka o imieniu Anastazy ${ }^{14}$.

${ }^{10}$ F. Brode1, Materiana cyvilizacija, ekonomika i kapitalizm, XV-XVIII s., t. I (Struktury povsiakdennosti: mozlyve i nemozlyve), Kyiv, s. 98-99.

11 J. Ovsińskyj, Filvarkove hospodarstvo Reči Pospolytoji XVIII s. v ocinci polskoji istoriografiji, Lviv 2005, Problemy slovjanoznavstva, vyp. 55, s. 29-40; id e m, Podilskyj filvarok u 20-30 rokach XVIII s.: osnovni typy ta struktura (na prykladi majetkiv Zevuśkych), Cerkasy 2008, Ukraińskyj selianyn. Zb. Naukovych Prać, vyp. 11, s. 135-145; ide m, Majetkovyj kompleks Zevuśkych na Podilli u XVIII s., [w:] Folwark, wieś, latyfundium. Gospodarstwo wiejskie w Rzeczypospolitej XVI-XVIII wieku, red. J. Muszyńska, S. Kazusek, J. Pielas, Kielce 2009.

${ }_{12}$ M. Hrusževśkyj, Istorija Ukrainy-Rusi, t. VI, Kyiv-Lviv 1907, s. 394; C.N. Apetrei, The Transit of Cretan wine in $16^{\text {th }}$ Century Moldavia..., s. 199-200.

${ }_{13}$ W. Łozińs ki, Życie Polskie w dawnych wiekach, Kraków1969, s. 102-103.

${ }^{14}$ J. Rey ch m a n, Orient w kulturze polskiego Oświecenia, Wrocław 1964, s. 99. 
Do tego teatru próżności aktywnie dołączyli również bogaci mieszkańcy miast. Wielu $z$ nich wcześniej nawiązało owocną współpracę z kupcami ze Wschodu. Niektórzy w roli ich faktorów, inni wynajmowali na potrzeby przywożonych towarów piwnice swoich domów. Tak czy inaczej dla wielu ówczesnych szybki zysk $z$ handlu był miara sukcesu i stał się powodem do naśladowania przybyszów ze Wschodu.

Wpływowi „Orientu” stosunkowo szybko uległy też władze miast. Wielokrotnie w księgach rachunkowych Lwowa znaleźć można dowody wręczania prezentów szczególnie ważnym gościom. Wschodnie przedmioty zajmują w nich bardzo ważne miejsce. Król Władysław II Jagiełło na swoje wesele dostał od Lwowa m.in. 300 cytryn $^{15}$. W 1494 r. miasto podarowało arcybiskupowi Andrzejowi Roża Boryszewskiemu beczkę (vas) piwa, dwa garnki (ollae) małmazji i dwie kłody (trunci) owsa ${ }^{16}$.

W czasie kolejnej wizyty we Lwowie króla Zygmunta III i królewicza Władysława miejscowi Rusini złożyli w prezencie królewiczowi „dywan dywdykowy, chustę indyjską i sztukę złotogłowiu”. Dodatkowo od całego społeczeństwa lwowskiego monarcha dostał dwa kilimy perskie, każdy o wartości 185 zł, i dwie sztuki złotogłowiu czerwonego i zielonego za $87 \mathrm{zł} 8 \mathrm{gr}^{17}$.

Kupcy greccy doskonale znali upodobania ówczesnych elit i umiejętnie korzystali z możliwości, które dawał im handel ze Wschodem. W karawanach kupieckich lub na małych statkach podróżowali między Aleppo, Stambułem i wyspami Morza Śródziemnego, spełniając każde życzenie gotowych zapłacić wysoką cenę za posiadanie wschodnich skarbów. Greccy kupcy pozostawali w cieniu Ormian i Żydów, nie mogąc w pełni z nimi konkurować. Dla większości Greków głównym przedmiotem handlu pozostawało wino ${ }^{18}$. My jednak proponujemy spojrzeć na towary, które dowożone $z$ beczkami muszkateli, alikante lub lemonii, zmieniały upodobania klientów i świat pogranicza.

Archiwa Lwowa pozwalają ustalić, że w XVI-XVII w. na liście przywożonych towarów greckich najczęściej wymieniane były dywany, stroje, tekstylia, broń, koce dla koni, biżuteria, przyprawy i słodycze. Nie tak często, ale odnotować można także „tureckie złoto”, kadzidło ${ }^{19}$, różnego rodzaju barwniki ${ }^{20}$ i konie.

${ }^{15}$ D. Zubryćkyj, Chronika mista Lvova, Lviv 2002, s. 75.

16 Ibidem, s. 114.

17 Ibidem, s. 232.

18 I. Lylo, Narysy z istoriji hrećkoji hromady mista Lvova, Lviv 2002, s. 41-42.

19 CPAHL, Fond. 52, Op. 2, Spr. 17, s. 776.

20 Do takich zaliczano błękit indygowy - barwnik wykorzystywany do farbowania skór. W transporcie tego barwnika do Rzeczypospolitej i dalej do Moskwy 
Wśród tych towarów szczególne wrażenie robią importowane do Polski tureckie (Halt) i perskie (Kelim) dywany ${ }^{21}$. Ich liczba trafiająca na miejscowy rynek jest obliczana na tysiące sztuk, a obecność tych produktów jest niemal obowiązkowa w opisach własności wszystkich Greków wędrujących lub mieszkajacych na stale na terenie Rzeczypospolitej. Spotykamy informacje o wspomnianych wyrobach w testamentach bogatych obywateli polskich miast greckiego i niegreckiego pochodzenia. Większość dywanów importowano w XVI i XVII w. $z$ terenów Anatolii, szczególnie $z$ perskiego Kurdystanu. Wiele $z$ nich pochodzi $z$ prowincji Kerman. Przez długi czas w polskiej literaturze identyfikowano je błędnie jako „staropolskie". Jednakże dokładna analiza wykazała różnice technologiczne w sposobie produkcji. Błąd często wynikał $z$ tego, że lokalni wytwórcy dywanów na terenie Polski w stosunkowo krótkim czasie osiagnęli wysoki poziom w ich wytwarzaniu, o czym powiemy nieco później. Osobom nieznającym się na wytwórstwie dywanów trudno było odróżnić replikę od oryginału ${ }^{22}$. Udanych prób własnej produkcji dokonano w manufakturach, które powstały m.in. w mieście Brody lub stolicy książąt Radziwiłłów - Nieświeżu ${ }^{23}$.

W naszej części Europy dywanami nakrywano nie tylko podłogi, lecz także stoły, dekorowano nimi ściany lub używano nawet jako zabezpieczenia finansowego ${ }^{24}$. W Rzeczypospolitej perskie dywany często miały własna nazwę - „adżam”, co tłumaczyło się jako „pers”. Towary te również cieszyły się dużym zainteresowaniem wśród zachodnich kupców którzy, wracając po udanej podróży na Wschód, przywozili je na wymianę. Grecy, oprócz wina i innych towarów, sprowadzali dywany ${ }^{25}$. W spisie majątku zmarłego we Lwowie w 1582 r. greckiego kupca o imieniu Sawa Grek liczba kilimów i różnego rodzaju strojów pochodzenia tureckiego zajmuje

wyróżniał się turecki kupiec Mehmet Czelebi w 1579 r. CPAHL, Fond. 52, Op. 2, Spr. 17, s. 7910-9110.

${ }^{21}$ Doskonała klasyfikację dywanów, a także metodę ich produkcji przedstawił swego czasu Tadeusz Mańkowski. Id e m, Orient $w$ polskiej kulturze artystycznej, Wrocław 1959, Studia z Historii Sztuki, t. VIII, s. 31-32.

${ }^{22}$ Idem, Ze studiów nad dawnym tkactwem Polskim. Z powodu wystawy $w$ instytucie propagandy sztuki, „Nike” 1938, R. II, z. 2, s. 7.

${ }^{23}$ W. Łozińs ki, Życie polskie $w$ dawnych wiekach, Warszawa 2006, s. 97.

${ }^{24}$ CPAHL, Fond. 52, Op. 2, Spr. 513, s. 692.

${ }^{25}$ Dokładny opis dywanów trafiających na polski rynek podano w: A. Dziubiński, Na szlakach Orientu - handel między Polska a Imperium Osmańskim w XVI-XVIII wieku, Warszawa 1998, s. 168-172. 
kilkanaście pozycji ${ }^{26}$. W 1591 r. Janij Afendyk sprowadził do Lwowa m.in. „kilimy, cztery tysiące skór safianowych, [...] i jeden kutasyk”. Część z tych towarów kupiec zabrał w dalszą podróż do Moskwy ${ }^{27}$.

W miejskich księgach Lwowa można znaleźć informacje z 1635 r., że Grek o imieniu Michał w swoim sklepie miał „kilimy haftowane złotem"28. Słynny grecki kupiec i producent Michał Korfiński we lwowskim magazynie ormiańskiego kupca Bartosza Norsesowicza miał 10 kilimów perskich, między nimi jeden haftowany złotem.

Franciszek Jaworski w swojej rozprawie o historii gmachu lwowskiego ratusza wspomina o wspaniałej kolekcji wschodnich kilimów i broni. Powstała ona dzięki darom delegacji zwiedzających Lwów i miejskim tłumaczom. Właśnie dzięki temu, że każdy tłumacz, a Grecy wśród tłumaczy stanowili czasami znaczna liczbę, pod koniec kolejnego roku oprócz zapłacenia podatku miał przekazać miastu oryginalny prezent, kolekcja szybko się bogaciła. Niestety, nie zachowała się do naszych czasów. W 1704 r. rozgrabiły ją wojska szwedzkiego króla Karola XII ${ }^{29}$. Poza Lwowem, według relacji świadków, dużą kolekcję dywanów w swojej posiadłości w Dubnie miał książę Konstanty Ostrogski ${ }^{30}$.

Dla wielu ówczesnych mieszkańców ziem polskich posiadanie wschodnich rzeczy było swoistym znakiem świadczacym o statusie społecznym. Jednak naszym zdaniem stosowanie wschodniego trendu w dekorowaniu domów lub modzie w większości przypadków nie było świadectwem wyboru cywilizacyjnego, lecz wyłącznie pragmatycznym podejściem do życia. Ówcześni mieszkańcy w trakcie budowania własnego materialnego swiata tworzyli na pograniczu bardzo ciekawa symbiozę zachodniej i wschodniej kultury ${ }^{31}$.

Andrzej Frycz Modrzewski zauważał różnorodność w ówczesnych strojach. Pisał: „w tym samym polskim domu jedna osoba może ubierać się na modę niemiecka, druga na włoską, podczas gdy trzecia hołduje modzie tureckiej, tak jak gdyby każdy $z$ domowników urodził się w innym obcym kraju, $z$ dala od pozostałych; ponadto

${ }^{26}$ Shidna torhivlia Lvova $v$ seredyni XVI - perszij polovyni XVII s., Zbirnyk dokumentiv, Uporiadnyk Kryvonos V. Lviv: LNU im. Ivana Franka 2011, s. 54-58; Oryginał: CPAHL, Fond. 52, Op. 2, Spr. 118, s. 954-959.

${ }^{27}$ CPAHL, Fond. 52, Op. 2, Spr. 21, s. 589-590.

${ }^{28}$ I. Sozańskyj, op. cit., s. 18.

29 F. J aw ors ki, Ratusz lwowski, Lwów 1907, s. 44.

30 J.T. Lubomirski, Regestra skarbca ks. Ostrogskich w Dubnie, „Sprawozdania Komisji do Badania Historii Sztuki", t. VI, Kraków 1900, s. 122.

${ }^{31}$ T. Mańkowski, Polskie tkaniny $i$ hafty XVI-XVII w., Wrocław 1954, s. 31. 
bywa, że ta sama osoba wkłada rankiem włoska pelerynę, $z$ wieczora zaś turecką fałszurę, kołpak i czerwone lub białe buty"32.

Zjawisko to, obserwowane i podziwiane przez innych przybyszów, zostało przez nich w ciekawy i rzetelny sposób opisane. Mieszkaniec Gdańska - Martin Gruneweg - w swojej relacji z podróży, pisząc o Lwowie, wspomina: „W tym mieście, jak i w Wenecji, stało sie zwyczajem, że na Rynku można spotkać ludzi z całego świata w ich ubraniach: Węgrów w ich małych filcowych czapkach, Kozaków w wielkich kuczmach, Rosjan w białych czapkach, Turków w białych turbanach. [...] Miasto ponad sto mil odległe od morza. Ale jak zobaczysz, jak na rynku przy beczkach malwazji nurtuje tłum Kreteńczyków, Turków, Greków, Włochów, wciąż ubranych jeszcze w stroje żeglarskie, wydaje się, że port tego miasta jest tuż za jego bramą"33. Włoski podróżnik Marcus Antonius Coccius, znany jako Sabellicum, w drugiej połowie XVI w., opisując wygląd mieszkańców Rzeczypospolitej, używał terminu graecanico similis, cokolwiek by to jego zdaniem nie znaczyło ${ }^{34}$.

Wśród mieszkańców wschodniego pogranicza Rzeczypospolitej odmienne stroje prezentowali Ormianie i Żydzi. Jak się wydaje, Grecy przejęli miejscowy sposób ubierania się głównie za sprawa lokalnej prawosławnej wspólnoty. Chociaż można założyć, że powód mógł być zupełnie inny. Od drugiej połowy XVI w. większość Greków napływajacych do Polski pochodziła $z$ terenów od wielu lat należących do Wenecji. Ich stroje przypominały te, które widzimy np. na obrazach włoskiego malarza Cesarego Vecellia ${ }^{35}$.

Tak czy inaczej możemy mówić o trwałej modzie na stroje i akcesoria orientalne. $Z$ czasem stały się one integralną częścią codziennego lub świątecznego ubrania. Grecy $z$ innymi kupcami sprowadzali do miast znaczne ilości tkanin, wśród których

${ }^{32}$ https://wolnelektury.pl/katalog/lektura/o-poprawie-rzeczypospolitej.html. O panujacej w Polsce modzie: J. Żukowski, W kapeluszu i $w$ delii, czyli ewenement stroju mieszanego $w$ dawnej Rzeczypospolitej, „Kwartalnik Historii Kultury Materialnej" 2009, nr 1, s. 19-37.

${ }^{33}$ Cyt. za: Martin Gruneveg (otec Venčeslav): duchounik Mariny Mniszek. Zapiski o torgovoj pojezdke v Moskvu v 1584-1585 g, sostavitel A.L. Horoszkevicz, Moskva 2013, s. 120.

${ }^{34}$ S. Kot, Polska złotego wieku wobec kultury zachodniej, [w:] Kultura staropolska, Kraków 1932, s. 645-646.

${ }_{35}$ Costumes anciens et modernes. Habiti antichi et moderni di tutto il Mondo di Cesare Vecellio précédés d'un essai sur la gravure sur bois par M. Amb, Paris 1859-1860, s. 402. 
największym zainteresowaniem cieszyły się „czamlet ${ }^{36 ” ~ i ~ „ m u c h a-~}$ jer ${ }^{37}$. Część $z$ tych towarów wysyłano przez Transylwanię ${ }^{38}$ na Morawy do Austrii i Norymbergi ${ }^{39}$.

Wśród bogatych mieszczan popularne były „kabaty”, które nazywano również „kasakami”. Szczególnym uznaniem ten krój ubrania cieszył się w okresie panowania królów Zygmunta III i Władysława IV. Ale w odróżnieniu od zachodniej części Rzeczypospolitej, gdzie mieszczanie stosowali prostą formę, już w Lublinie „kasaki” zdobiono orientalnymi dodatkami i doszywano długie rękawy.

Wpływ orientalny na sposób ubierania się można szczególnie zauważyć w strojach damskich, które szyto $z$ wysokiej jakości importowanych tkanin. Noszenie gotowych ubrań wschodnich było niemożliwe, głównie ze względów zwyczajowych i klimatycznych. Wspomniany Martin Gruneweg wyraźnie zaznacza, że większość kobiet we Lwowie na swój sposób preferowało „niemiecki” styl w ubraniach ${ }^{40}$. Ale jednocześnie mieszczanki Lwowa lub Przemyśla dość chętnie łączyły krój zachodni z romantycznymi i barwnymi elementami Orientu.

Polska szlachta bardzo chętnie prezentowała za granica swoje bogactwo i odmienność w sposobie ubierania się. Tak opisywano słynny wjazd do Rzymu poselstwa księcia Jerzego Ossolińskiego w 1633 r.: „Dalej postępowali służący, prowadzący pięć koni tureckich. Siodło pierwszego sadzone było diamentami, drugiego turkusami, trzeciego rubinami, czwartego różnymi drogimi kamieniami, zaś piątego, wyjątkowo piękne, świeciło diamentami [...]. Na głowie miały konie kosztowne kity. Dwa $z$ nich miały złote podkowy, które, umyślnie źle przymocowane, rozpadły się. Prowadzili je Tatarzy i Ormianie"41.

36 „Czamlet” znany w Polsce też jak „kamlot” - materiał z włosów kozy lub wełny owczej; gatunek tkaniny wełnianej. Używany do produkcji płaszczy. We Lwowie i innych miastach używano do produkcji spódnic. CPAHL, Fond. 52, Op. 2, Spr. 13, s 911-913.

37 „Muchajar” - tkanina gruba, rodzaj sukna tkanego $z$ sierści koziej, po turecku nazywa się muchajjer lub muchajjar. Muchair bywał turecki, wenecki lub niemiecki, czarny dwunitowy i jednonitowy.

${ }^{38}$ L. Ge c s é ny i, "Turkish goods” and „Greek merchants” in the Kingdom of Hungary in the $16^{\text {th }}$ and $17^{\text {th }}$ c., "Acta Orientalia Academiae Scientiarum Hungariae” [Budapest] 2007, vol. LX (I), s. 55-71.

${ }^{39}$ S. Kutrzeba, Handel Krakowa w wiekach średnich na tle stosunków handlowych Polski, „Rozprawy Polskiej Akademii Umiejętności. Wydział Historyczno-Filozoficzny" 1903, t. XLIV, s. 128.

40 Martin Gruneveg (otec Venčeslav)..., s. 136.

${ }^{41}$ T. Makow s ki, Przesławny wjazd Jerzego Ossolińskiego do Rzymu (Najsłynniejsze polskie poselstwo do papieża w 1633 r.), „Spotkania z Zabytkami” 2007, 
Peter Paul Rubens, na obrazie, który przedstawia królową koczowniczego plemiona Massagetów - Tomyris, w celu prezentacji jej środowiska użył stroju charakterystycznego dla polskiej szlachty XVII w. Być może, według malarza, było to najlepsze odzwierciedlenie, w zachodnim wyobrażeniu, pojęcia europejskiego „Wschodu”42. Podobne uczucia miał francuski kronikarz J. Laboureur, opisując w 1648 r. wygląd polskich ambasadorów, którzy przyjechali, by powitać królową Marię Luizę Gonzagę de Nevers ${ }^{43}$.

Właśnie wówczas, kiedy moda na towary wschodnie pod koniec XVI i w pierwszej połowie XVII w. osiągnęła swój szczyt, Grecy aktywnie wykorzystali dobra dla nich koniunkturę, oferując towary na każdy gust i każdą kieszeñ ${ }^{44}$.

Wielkim zwolennikiem kultury wschodniej był król Jan III Sobieski. Źródła potwierdzają, że do końca życia monarcha zachwycał się „Orientem” w różnych jego przejawach. Na dworze patronował ormiańskim i greckim rzemieślnikom produkującym na jego zamówienie pompony dla koni (czapraki) i wysokiej jakości kołczany ${ }^{45}$. Istnieją liczne wzmianki o popularności na dworze potraw śródziemnomorskich. Wystarczy tylko spojrzeć na przepisy w opublikowanych ostatnio najstarszych staropolskich książkach kucharskich ${ }^{46}$.

nr 9, s. 11; idem, Z dziejów stosunków państwa i Kościoła. Polskie poselstwa obediencyjne w XVI i XVII wieku, „Teologia Polityczna” 2003-2004, nr 1, [Warszawa 2004], s. 203; M. Barłows ka, Poselstwo Jerzego Ossolińskiego do Rzymu w 1633 r., http://www.wilanow-palac.pl/poselstwo_jerzego_ossolinskiego_do_rzymu_w_1633_r.html (dostęp: 31 V 2016). Widoki wjazdu widnieją na obrazach Stefano della Belli Entrata in Roma dell' ambasciatore G. Ossoliński, które znajduja się w zbiorach Biblioteki Narodowej w Warszawie; J. Talbierska, J. Stefano Della Bella - Etchings from the Collection of the Print Room of the Warsaw University Library, Varsavia 2001.

${ }^{42}$ Peter Paul Rubens, Head of Cyrus Brought to Queen Tomyris, ca. 1622/23, oil on canvas, 205,1 × $361 \mathrm{~cm}$ (Boston, Museum of Fine Arts, William I. Koch Gallery).

43 T. Mańkowski, Barok, orientalizm i sarmatyzm, „Sprawozdania Polskiej Akademii Umiejętności" 1934, t. XXXIX, nr 8, s. 3. Oryginał: J. Le Laboureur, Relation du voyage de la Reine de Pologne, et du retour de Madame la Mareschalle de Guébriant... par la Hongrie, L'Austriche, Styrie, Carienthie, le Frioul, l'Italie. Avec un discours historique de toutes les villes et Estats per où alle a passé, Paris 1647.

${ }^{44}$ M. Zakrzewska-Dubasowa, Ormianie zamojscy $i$ ich rola $w$ wymianie handlowej i kulturalnej między Polska a Wschodem, Lublin 1965, s. 138.

${ }^{45}$ Ibidem, s. 161.

${ }^{46}$ J. Dumanowski, A. Pawlas, J. Poznański, Sekrety kuchmistrzowskie Stanisława Czernieckiego, Warszawa 2012; Ksiega szafarska dworu Jana III Sobieskiego 1695-1696, oprac. J. Dumanowski, M. Próba i Ł. Truściński, red. J. Dumanowski, Warszawa 2013, Monumenta Poloniae Culinaria, t. IV. 
Ówczesna kuchnia polsko-ukraińskiego pogranicza to temat oddzielny, wciąż jeszcze mało znany. „Jesteśmy tym, co jemy” - to powiedzenie pozwala nam spojrzeć na ówczesne preferencje żywieniowe zamożnych mieszczan i szlachty. Regularnie używali przypraw pochodzących znad wschodniej części Morza Śródziemnego. W 1408 r. mołdawski hospodar Aleksander pozwolił kupcom ze Lwowa handlować na jego ziemiach m.in. „kwasem greckim"47. W 1456 r. kolejny mołdawski władca - Piotr III, wydał przywilej, na mocy którego kupcy ze Lwowa i Podola mogli handlować na ziemiach Rzeczypospolitej "greckim kwasem” z imbirem ${ }^{48}$.

Dokumenty celne $z$ archiwów Lwowa pełne są wzmianek o importowanych przez Greków i Ormian towarów takich jak pieprz ${ }^{49}$, oliwki ${ }^{50}$, sok $z$ cytryn ${ }^{51}$. W 1481 r. biskup Jan Strzelecki, $z$ okazji powrotu do stolicy, otrzymał w darze od Lwowa „kamień pieprzu, cztery garnce malwazji, i czterysta cytryn" 52 . W 1676 r. Jani Greczyn sprowadził do Lwowa wielki transport rodzynek i fig ${ }^{53}$. Jeden $z$ najbardziej znanych obywateli miasta - Grek z Krety o imieniu Konstanty Korniakt, często przyjmował w swojej kamienicy położonej przy rynku wybornych gości, którzy delektowali się winami przywożonymi z krajów znad Morza Śródziemnego. Autor najstarszej polskiej książki kucharskiej Stanisław Czerniecki, który w swych przepisach dbał o utrzymanie „czystości” kuchni regionalnej, uznał jednak już za tradycję serwowanie do wielu lokalnych potraw śródziemnomorskich win ${ }^{54}$.

Bardzo popularnym towarem importowanym były tzw. zioła tatarskie, mieszanina roślin występujących tylko na Wschodzie. Wykorzystywano je zarówno w kuchni jako przyprawy, jak i w lecznictwie. W 1591 r. 29 worków tych ziół sprowadził do Lwowa Grek Jani Afendyk ${ }^{55}$. W 1548 r. w Piotrkowie król Zygmunt I nakazał mieszkańcom Lublina, aby sprowadzone $z$ Grecji i Turcji zioła sprzedawano dopiero po rzetelnym ich zbadaniu i w odpowiednio wyznaczonym do tego miejscu ${ }^{56}$.

${ }^{47}$ Pryvileji mista Lvova..., s. 519.

48 CPAHL, Op. 2, F. 131, Spr. 160. Pryvileji mista Lvova..., s. 529.

49 CPAHL, Fond. 52, Op. 2, Spr. 17, s. 777-778.

50 Ibidem, Spr. 247, s. 1173.

51 Ibidem, Spr. 243, s. 421.

52 D. Zubryćkyj, op. cit., s. 111.

53 CPAHL, Fond. 52, Op. 2, Spr. 837, s. 103.

54 J. Dumanowski, A. Pawlas, J. Poznański, op. cit., s. 44.

${ }^{55}$ CPAHL, Fond. 52, Op. 2, Spr. 121, s. 589-590.

${ }^{56}$ Katalog dokumentów Archiwum Państwowego w Lublinie, cz. 2 (Katalog dokumentów różnej proweniencji miast, wsi, cechów, parafii, klasztorów i osób prywatnych), oprac. M. Trojanowska, Lublin 1998, s. 73; R. Rybarski, op. cit., s. 153. 
Mamy stosunkowo mało informacji na temat wpływów stylu orientalnego w dekorowaniu wnętrz. Niektórzy bogaci mieszczanie zdobili ściany swoich mieszkań tzw. włoskimi ${ }^{57}$ lub tureckimi tapetami ${ }^{58}$. Większość magnatów w swoich domach i pałacach wzorowała się raczej na zachodnioeuropejskiej modzie. Ale były wyjątki: biskup lwowski Jan Zamojski do dekoracji własnej kaplicy w katedrze sprowadził ze Wschodu 20 dywanów z haftowanymi osobistymi monogramami ${ }^{59}$. We Lwowie i Jarosławiu powstało kilka dworów na wzór wschodniego „fonduku”, z charakterystycznymi dużymi podwórkami i otaczajacymi je galeriami ${ }^{60}$.

Grecy osiedlajacy się w miastach ziem wschodnich zazwyczaj kupowali domy o regionalnej architekturze. Sposób zabudowy miast, wielkość domów i warunki klimatyczne nie pozwalały na tworzenie budowli w stylu architektury Wschodu. Nawet pałac najbogatszego Greka Lwowa - Konstantego Korniakta, jest przykładem renesansowej architektury. Stanowi dzieło włoskiego architekta Petra Barbona ${ }^{61}$. Kiedy dzięki dokładnemu opisowi majątku lwowskiego Greka Kiryjaka Papary „wirtualnie” zwiedzamy pokoje i korytarze jego kamienicy, nie odnajdujemy tam „ducha wschodniego"62.

Każdy kolejny konflikt $z$ Turcją przyczyniał się do większego napływu łupów ze Wschodu. Według Władysława Łozińskiego zwycięstwa nad Turkami jeszcze bardziej podsycały modę na Orient. To zjawisko wydaje się o wiele ważniejsze od codziennej żmudnej pracy kupców ${ }^{63}$. Obrazy takich artystów, jak Martino Altomonte pokazuja, jak mała była różnica w sposobie ubierania się na polu bitwy między polska szlachta a Turkami lub Kozakami. Nie tylko dla ozdoby, lecz także dla odróżnienia używano skóry lamparta lub futra tygrysa. Właśnie takie skóry miał w swoim transporcie w 1630 r. lwowski jubiler Stanisław Niklewicz ${ }^{64}$. Zmiany dotyczyły nie tylko wojskowej, lecz także codziennej „mody”. Ewolucja tego

57 CPAHL, Fond. 52, Op. 2, Spr. 517, s. 314-315.

58 Ibidem, Spr. 18, s. 956.

59 „Sprawozdania dla badania historii w Polsce” 1856, t. V, s. 322.

${ }^{60}$ A. Dziubiński, op. cit., s. 66.

${ }^{61}$ Kamianycia Korniakta: Korolivśki zaly: putivnyk Olha Perelyhina, Marija Hul', Myroslav Pobereznyj; LIM, Kyiv 2010.

62 CPAHL, Fond. 52, Op. 1, Spr. 677, s. 1-2.

${ }^{63}$ W. Łozińs ki, Życie polskie $w$ dawnych wiekach, Kraków 1969, s. 161.

${ }^{64}$ CPAHL, Fond. 52, Op. 2, Spr. 145, s. 2156; ibidem, Op. 1, Spr. 517, s. $1085-1086$. 
procesu jest oczywista na przykładzie portretów trumiennych, które znajdują się w zbiorach Muzeum Historycznego we Lwowie ${ }^{65}$. Między wizerunkiem Konstantego Korniakta a portretem jego wnuka Antoniego-Karola Korniakta $z$ podpisem „Antonius Korniakt urbimus de Familia magnarum Quandam in Terra Premisliensi Ditionum Nacres" istnieje ogromna różnica.

Przybywające ze Wschodu poselstwa miały wpływ na ówczesna modę posiadania dobrej jakości broni wschodniej, głównie produkcji tureckiej lub arabskiej66. Pierwsze wzorce zdobywano w walce lub podczas podróży. Największą wartość miała oryginalna broń kupiona lub zdobyta na wrogu $z$ sentencja poprzedniego właściciela. Mimo tego, że Imperium Osmańskie zakazywało wywozu z kraju broni, kupcy potrafili ten zakaz ominąć. Jednym $z$ najbardziej rozpowszechnionych sposobów było dorabianie rękojeści do ostrza szabli. Głównymi „importerami” broni ze Wschodu byli Ormianie ${ }^{67}$. Ale dość często możemy spotkać wśród handlarzy bronią również greckie nazwiska. Grek Jani Afendyk w 1578 r. sprowadził do Lwowa na sprzedaż 11 szabli tureckich, dwie tarcze perskie i siedem czapraków dla koni ${ }^{68}$. Ponowne informacje o nim pojawiają się w $1591 \mathrm{r}$., gdy w jego magazynie odnotowano 13 szabel i dwa konie dobrudżańske ${ }^{69}$. Kiedy we Lwowie w czasie podróży zmarł kupiec grecki Dymitr Markoczan, to Jani Afendyk dostał w spadku jego szable ${ }^{70}$. Sawa Grek miał na sprzedaż „szabel krzywych i prostych siedem po pięć florenów. Prostych szabel za jeden fl jeden zł - pięć"11. Władysław Łoziński wspomina, że bronią handlował i Gabriel Langish ${ }^{72}$. W 1602 r. na liście towarów, którymi kupiec Zachariusz Iwaszkiewicz rozliczył się z Grekiem Dymitrem Juryjewiczem z Zamościa, było kilka różnych pozycji broni ${ }^{73}$. Ówczesna władza zdecydowała, że tylko Grecy, którzy byli mieszkańcami Lwowa, mogli sprzedawać

${ }^{65}$ W. Deluga, Greek Patronage of the Arts in Lviv in the Sixteenth and Seventeenth Centuries, [w:] Economy and Society in Central and Eastern Europe. Territory, Population, Consumption, eds D. Dumitran, V. Moga, Berlin-Zürich 2013, s. 294; H. J akuženko, Kataloh zbirky zyvopusu Lvivskoho istorycznoho muzeju, Lviv 1987, s. 76.

${ }_{66}^{6}$ M. Hrusževśkyj, Istorija Ukrainy-Rusi..., t. VI, s. 65.

67 T. Mańkowski, Orient..., s. 131.

68 CPAHL, Fond. 52, Op. 2, Spr. 121, s. 591.

69 Ibidem, s. 590.

70 Ibidem, Spr. 718, s. 1.

${ }^{71}$ Ibidem, Spr. 18, s. 955.

${ }^{72}$ W. Łoziński, Patrycyat..., s. 321.

${ }^{73}$ CPAHL, Fond. 52, Op. 2, Spr. 1517, s. 314. 
broń: „Szkoci, Grecy i Żydzi mają zakaz na handel bronią z wyjątkiem wyznaczonych dni targowych"74.

Powróćmy jeszcze do rynku akcesoriów. Wspomnieliśmy, że były one bardzo popularne w środowisku polskich, ukraińskich lub greckich mieszczek ${ }^{75}$. Ale ta moda skutecznie przeszła na mężczyzn. Bogaci często dekorowali swoje stroje oryginalnymi guzikami, chustami, szczególnie zaś perskimi i tureckimi pasami ${ }^{76}$. Ten ostatni element stroju osiagnął szczyt popularności w drugiej połowie XVII w. Ceny pasów były różne: za pas zwykły turecki płacono $6 \mathrm{zl}$, stambulski - $12 \mathrm{zl}$, polski - $16 \mathrm{zl}$, a za sprowadzony $\mathrm{z}$ miasta Bursa - 28 zł. Niekiedy spotykamy pasy w cenie prawie fortuny, bo nawet za $50 \mathrm{zl}$. Poza bronia pas był drugim ważnym elementem stroju szlachcica. Świadczył o zamożności jego posiadacza. $Z$ upływem czasu pasy wzorowane na styl wschodni stały się obowiązkowym elementem polskiego stroju. Grecy mieli w tym swój udział. W magazynie tylko jednego Greka o imieniu Sawa w 1582 r. naliczono 84 pasy pochodzace $z$ miasta Bursa $^{77}$.

Wśród wschodnich towarów popularne było, szczególnie w łaźniach miejskich, tzw. greckie mydło. We Lwowie wyróżniano kilka gatunków tego produktu. W dokumentach napotykamy na mydło "greckie, tureckie, arabskie i zamorskie". W 1530 r. w dokumentach celnych w Lublinie odnotowano kilka brył mydła polskiego, ale i kilkanaście „greckiego"78. W XVI-XVII w. w syryjskim Aleppo produkowano mydło, które sprzedawano za granicę świata muzułmańskiego. Andrzej Dziubiński wspomina o kupcach syryjskich, którzy sprowadzali ten produkt w znacznych ilościach do Kamieńca Podolskiego i Lwowa. Mydło nazywane „greckim” różniło się tym od innych gatunków, że dodawano do niego w czasie produkcji olejek $z$ oliwy i inne ekstrakty ziołowe ${ }^{79}$. Wzmianki o mydle często spotykamy obok informacji o „ręczniku tureckim dla łaźni” i „białych chustach do wycierania”.

${ }^{74}$ W. Łozińs ki, Ormiański epilog lwowskiej sztuki złotniczej, „Sprawozdania Komisji do Badania Historii Sztuki w Polsce” [Kraków] 1901, t. VII, z. 1-2, s. 251.

${ }^{75}$ M. Zakrzewska-Dubasowa, op. cit., s. 131. Wśród złotników z przedmieścia Lwowa, których uważano za partaczy, w 1580 r. wymienione jest imię: „olim honestus Dymitr Grecyzyn aurifaber de suburbio Leopoliensi iurisdictionis huius”. F. Bost e1, Przyczynki do dziejów złotnictwa lwowskiego, [w:] „Sprawozdania Komisyi do Badania Historii Sztuki w Polsce" [Kraków] 1896, t. V, s. 18-19.

${ }^{76}$ M. Zakrzewska-Dubasowa, op. cit., s. 120.

77 CPAHL, Fond. 52, Op. 2, Spr. 118, s. 954.

${ }^{78}$ R. Rybarski, op. cit., s. 187.

${ }^{79}$ A. Dziubiński, op. cit., s. 182.

${ }^{80}$ CPAHL, Fond. 52, Op. 2, Spr. 118, s. 954-959. 
Wydawać by się mogło, że popularność produktów wschodniego pochodzenia w codziennym życiu mieszkańców Rzeczypospolitej $z$ czasem doprowadzi do ich dominacji. Ale tak się nie stało. Wielu obywateli pochodzenia greckiego, ormiańskiego lub żydowskiego zdobywajac fortuny na handlu ze Wschodem, osiedlając się na stałe w polskich miastach, zainteresowało się zachodnią kulturą materialna. Potwierdzeniem tego sa zachowane do naszego czasu zapisy w testamentach ${ }^{81}$. Zofia Afendykowa w spadku dla potomków pozostawiła m.in. łyżeczki pozłocone $z$ "chłopkami” udekorowane głowami lwów (cum effigie capitis leonis) ${ }^{82}$. Na liście rzeczy spisanych w testamencie Michała Alwiziego znajdujemy więcej informacji o pozłacanej figurce konia produkcji augsburskiej niż o dywanach perskich $^{83}$. Nawet $\mathrm{w}$ kwestii religii część Greków zafascynowana była tradycją łacińską ${ }^{84}$.

Jesteśmy przekonani, że nie wolno patrzeć na rynek ówczesnej Europy Wschodniej w tradycyjnych relacjach Wschód-Zachód. Nowe trendy gospodarcze panujace na tym terenie stworzyły nowe priorytety i wymagania dla wymiany handlowej. Grecy $z$ innymi grupami kupców szybko dostosowali się do nowych realiów i oprócz wschodnich towarów proponowali zachodnie, np. sukno i inne tkaniny. W 1609 r. znany kupiec Jan Baptysta sprowadził do Mołdawii 630 sztuk płótna. W 1624 r. Gabriel Langish wysłał do Kamieńca Podolskiego swego pośrednika, który dla hospodara Mołdawii przywiózł odzież poprzednio zamówiona i uszyta we Lwowie ${ }^{85}$. Z czasem kupcy, w tym np. z Krakowa, próbowali zdobyć we Lwowie rynek odzieżowy. Część z nich założyła niewielkie warsztaty z myślą o przyszłym eksporcie strojów do Mołdawii i Wołoszczyzny. Te próby jednak nie powiodły się przede wszystkim $z$ powodu oporu miejscowych wytwórców. Można powiedzieć, że do XVII w. wytworzył

${ }^{81}$ Ibidem, Fond. 52, Op. 2, Spr. 134, s. 329-331; Spr. 335, s. 353--355, s. 661-662, 665-667, s. 831, 841-842; Spr. 337, s. 39-66, 89-92, 160-169, 113-114, 237-244, 314-318, 453-454, 454-455; Spr. 338, s. 459-463; Spr. 341, s. $47-51,334-338$.

82 W. Łoziński, Złotnictwo lwowskie w dawnych wiekach 1384-1640, Lwów 1889 , s. 9.

${ }^{83}$ Ibidem, s. 11.

${ }^{84}$ W 1586 r. członkowie Bractwa Stawropigialnego we Lwowie złożyli skargę do biskupa Grzegorza Bałabana z powodu świętowania Wielkanocy. F. Sribnyj, Studiji nad orhanizacijeju Lvivskoji Stavropihiji vid kińca XVI do perszoji polovyny XVII s., Zapysky NTŠ, Lviv, t. CVIII, s. 19.

${ }^{85}$ CPAHL, Fond. 52, Op. 2, Spr. 139, s. 612-615. 
się oryginalny i ciekawy styl, który pozostając zachodni, jednoczył w sobie wpływy wschodnie. Niewątpliwie wyróżniał polską szlachtę i mieszczan od reszty świata zachodniego.

Brak stabilności w regionie od lat trzydziestych XVII w. doprowadził do wzrostu cła i cen na towary luksusowe. Wykorzystali to Grecy, zakładając warsztaty produkujace poszukiwane towary na terenie Kresów. W pierwszej kolejności były to wyroby złotników i tkaczy ${ }^{86}$. Największy ośrodek powstał w Brodach, gdzie między 1640 i 1650 r. mieszkało kilku greckich rzemieślników ${ }^{87}$.

Tradycja produkcji tkanin sięga jeszcze czasów Bizancjum. Nie zaniknęła po upadku imperium głównie dzięki emigracji wielu fachowców do sąsiednich krajów. Na naszym terenie taką osobą stał się Manuel (Michał) Korfiński. Pochodził $z$ wyspy Korfu i początkowo znany był jako kupiec. Od 1641 r. $z$ innym mistrzem o imieniu Konstanty Stamowski (Stamati) opanowali w Brodach produkcję tkanin na wzór wschodni ${ }^{88}$. Rok wcześniej, w 1640 r., Manuel Korfiński otrzymał prawa miejskie w Brodach ${ }^{89}$.

Ich warsztatom patronował właściciel miasta, hetman Stanisław Koniecpolski, który przebywając jakiś czas w tureckiej niewoli, miał okazję poznać bliżej sztukę Wschodu. Chcac zmienić swoją własność w bogate centrum handlu i przemysłu, zaczął od prób hodowli w Brodach jedwabnika morwowego ${ }^{90}$. Zaprosił do miasta znawców jedwabników - Abrahama Fentzeliusa i Joachima Fiberantiusa. Niestety, produkcja okazała się zbyt kosztowna. Wtedy powrócił do pomysłu współpracy z Grekami ${ }^{91}$. Zaprosił ich do miasta, osiedlając obok Szkotów i Ormian już mieszkających w Brodach. Od początku Grecy wyróżniali się swoją odrębnością. Jako ziomkowie wspierali się nawzajem. Posiadając w Brodach dwa domy, Manuel Korfiński jeden $z$ nich sprzedał swojemu znajomemu Andrzejowi Atanasowiczowi za $700 \mathrm{zl}^{92}$.

86 „Sprawozdania dla Badania Historii w Polsce” 1856, t. V, s. 322.

87 T. Mańkowski, Orient..., s. 40.

88 Ibidem, s. 15.

89 „złotogłownik, miesczanin i kupiec brodzki, auritextor, civis et negotiator Brodensis famatus" - I. Sozańskyj, op. cit., s. 14.

90 T. Mańkowski, Sztuka islamu $w$ Polsce $w$ XVII i XVIII wieku, Kraków 1935, s. 11.

${ }^{91}$ Idem, Zachód $i$ Wschód $w$ tkactwie polskim XVII wieku (tkacze Koniecpolskich), Kraków 1932, s. 20

${ }^{92}$ I. Sozańskyj, op. cit., s. 26. 
Manuel Korfiński zaprosił do współpracy innych rzemieślników z Grecji i ze Lwowa. W 1643 r. celowo odwiedził Konstantynopol, gdzie udało mu się przekonać do przyjazdu do Brodów złotnika o imieniu Grzegorz, który kupił w tym celu specjalne urządzenia na kwotę 650 talarów. $Z$ czasem dołączył do nich miejscowy Żyd - Kemal. Na początku produkcja ich spółki ac si in ipsa Persiade miała problemy ze zbytem towarów. Dla poprawy sytuacji M. Korfiński zaciagnął duży kredyt. Warsztat, który pracował w gmachu miejskiego ratusza, $z$ czasem zdobył renomę i jedynym problemem było to, że Kemal zaczał okradać swoich partnerów, co doprowadziło do ich rozstania ${ }^{93}$.

W 1644 r. M. Korfiński przeniósł się z Brodów do Lwowa. Władysław Łoziński podaje, że w podmiejskim dworku należącym do wojewody bełskiego Krzysztofa Koniecpolskiego Korfiński ponownie zaczął produkcje tkanin ${ }^{94}$. Wśród jego uczniów spotykamy zarówno Polaków, jak i Rusinów. Tadeusz Mańkowski wymienia „Jacka, syna Łukasza Suchodolskiego, Tymka, syna Wasyla Grabarza, Jana Przyłuckiego i Piotra Starszego" ${ }^{95}$. We Lwowie M. Korfiński na pewno miał kontakty $z$ innym Grekiem, Aleksandrem Dymowiczem $z$ Konstantynopola. W 1637 r. rada miasta Lwowa wydała zgodę na budowę manufaktury dla produkcji złotej i srebrnej nici, używanej w złotogłowiach ${ }^{96}$. Od 1646 r. prawo na zarządzanie manufaktura przekazano innemu Grekowi - Michałowi Alwizie. Działania wojenne, szczególnie po powstaniu Bohdana Chmielnickiego, bardzo negatywnie wpłynęły na produkcję, chociaż istnieją informacje o funkcjonowaniu manufaktury także w drugiej połowie XVII w.

Ważne jest to, że M. Korfiński reprezentował w Polsce zupełnie nowy kierunek greckiej emigracji. Od początku Grecy dążyli do szybkiej integracji ze środowiskiem miejscowej elity gospodarczej. W odróżnieniu od członków Bractwa Stauropigialnego nie wiązali swojej przyszłości z kultura prawosławną. Dzięki ich działalności powstały nowe, ważne podmioty gospodarcze. Ale najważniejszym osiagnięciem jest to, że pozostawili po sobie grupy miejscowych uczniów, zdolnych na bardzo wysokim poziomie jakościowym

93 Ibidem, s. 27.

94 „Sprawozdania dla badania historii w Polsce” 1856, t. V, s. LXIII.

95 T. Mańkowski, Zachód i Wschód..., s. 20.

96 „Alexsander Dymowicz Graecus Constantinopolitanus opifex fila videlicet ductilia ex auro et argento operando et ex arte elaborando, alias ciagnione złoto i srebro [...]". CPAHL, Fond. 52, Op. 2, Spr. 45, s. 1512. 
kontynuować produkcję tkanin w stylu wschodnim ${ }^{97}$. Miejscowi chętnie oddawali swoje dzieci na naukę do M. Korfińskiego, mimo że miał on reputację bardzo srogiego nauczyciela, o czym świadcza skargi napływające od oburzonych rodziców.

Po likwidacji manufaktury M. Korfińskiego w Brodach nadal istniały warsztaty związane $z$ produkcja tkanin. Przykładem może być Iwan Haptiar, który „srebrem robił na czarnym łubie”, lub majster Marko, o którym informacje znajdujemy jeszcze w $1679 \mathrm{r} .{ }^{98} \mathrm{~W} 1666 \mathrm{r}$. odnajdujemy wzmianki o mieszczaninie Iwanie Kyrylowiczu „złotogłowniku". Zanotowano też wzrost liczby osób o podobnych zawodach, co było skutkiem naśladowania kolejnego Greka o imieniu Aleksander, który pracował w Brodach od 1639 r., haftując rękawice i kołczany. Dopiero od końca XVII w. rzemiosło to przeszło pod kontrolę miejscowych Żydów. W XVIII w. część warsztatów produkujacych pasy zostały przemieszczona ze Stambułu do Lwowa, a stąd dalej na tereny Rzeczypospolitej ${ }^{99}$.

W znacznym stopniu dzięki takim ludziom, jak M. Korfiński w kulturze materialnej polsko-ukraińskiego pogranicza pojawił się fenomen szlacheckiego barokowego sarmatyzmu. Jego apologeci - głównie szlachta, opierała się na przekonaniu, że pochodzi ona od starożytnego ludu Sarmatów, zamieszkującego początkowo między Dolna Wołga a Donem. Po Sarmatach szlachta miała odziedziczyć umiłowanie wolności, gościnność, dobroduszność, męstwo oraz odwagę. Grecy i inni kupcy oraz wschodni wytwórcy mieli wpływ na zewnętrzną otoczkę tego zjawiska ${ }^{100}$. Starano się podkreślić własny, oryginalny wzór, a jednocześnie pozostać w kręgu panującej ogólnie europejskiej tradycji barokowej. „Magicznemu” urokowi sarmatyzmu ulegli nawet naturalizowani Niemcy, jak kronikarz Marcin Gruneweg ${ }^{101}$.

${ }_{97}$ T. Mańkowski, Zachódi Wschód..., s. 18.

${ }^{98}$ I. Sozańskyj, op. cit., s. 8.

99 T. Mańkows ki, Barok..., s. 3.

100 Id e m, Genealogia sarmatyzmu, Warszawa 1946; id em, Orient $w$ polskiej kulturze artystycznej, Wrocław-Warszawa-Kraków 1959; A. Andjal, Manieryzm, sarmatyzm, barok, „Przegląd Humanistyczny” 1962, nr 1, s. 51-69; S. Cy na r ski, Sarmatyzm - ideologia i styl życia, [w:] Polska XVII wieku. Państwo. Społeczeństwo. Kultura, Warszawa 1969, s. 210-235; J. Tazbir, Rzeczpospolita $i$ świat. Studia z dziejów kultury XVII wieku, Warszawa 1971; J. Maci j jow s ki, Sarmatyzm jako formacja kulturowa, „Teksty” 1974, nr 4, s. 5-26; T. Venclova, Mit o poczatku, ibidem, s. 102-113; C. Hernas, Barok, Warszawa 1973; L.I. Tatanajeva, Sarmatkij portret. Iz istorii polskogo portreta epoki barokko, Moskva 1979.

101 Martin Gruneveg (otec Venčeslav)..., s. 108. 
Możemy dojść do wniosku, że Grecy i inni przedstawiciele Orientu w XVI i XVII w., będąc we właściwym miejscu i we właściwym czasie, umiejętnie wykorzystali sytuację, która panowała w tym czasie na ziemiach Rzeczypospolitej. Mieli z tego oczywiste i wymierne korzyści materialne, ale ich działalność nie miała decydującego wpływu na ogólny charakter społeczno-kulturowych wartości mieszkańców regionu.

\section{Bibliografia}

\section{ŹRódea ARChiWALNe}

Archiwum Państwowe w Krakowie

Dyplomy pergaminowe, nr 70.

Centralne Państwowe Archiwum Historyczne Ukrainy we Lwowie

Fond. 52, Op. 1, Spr. 677.

Fond. 52, Op. 2, Spr. 13, 17, 18, 21, 45, 118, 121, 131, 134, 139, 145, 160, 243, 247, 335, 337, 338, 341, 513, 517, 613, 718, 837, 1153, 1517.

\section{$\dot{Z}_{\text {RÓDEA DRUKOWANE }}$}

Battistelli A., La republica di Venezia, Venezia 1897.

Pryvileji mista Lvova (XIV-XVIII s.), uporiad M. Kapral, Lviv 1998.

Zubryćkyj D., Chronika mista Lvova, Lviv 2002.

\section{OpRacowania}

Andjal A., Manieryzm, sarmatyzm, barok, „Przegląd Humanistyczny” 1962, nr 1, s. 51-69.

Apetrei C.N., Greek merchants in Romanian Principalities in the $16^{\text {th }}$ c.: The case of Nicolaos Domesticos Nevridis, „ISTROS” [Brâila] 2011, vol. XVII, s. 95-121.

Apetrei C.N., Rethinking the connections of a sixteenth century family. The Korniakt

Merchants and Moldavia from 1540 to 1570, „ISTROS” [Brâila] 2014, vol. XX, s. 565-583.

Apetrei C.N., The Transit of Cretan wine in $16^{\text {th }}$ Century Moldavia. The European Context and Quantitative Assessments, „Transylvanian Review” 2013, vol. XXII, Supplement, No. 2 (Economic and Social Evolutions at the Crossroads of the World-System. Eastern and Central Europe from the Early Modern Age to the Twentieth Century), s. 193-203.

Bailly A., La république di Venize, Paris 1946.

Ballison K.T., Genoa and the Sea: Policy and Power in an Early Modern Maritime Republic, Washington 2005. 
Barłowska M., Poselstwo Jerzego Ossolińskiego do Rzymu w 1633 r., http://www. wilanow-palac.pl/poselstwo_jerzego_ossolinskiego_do_rzymu_w_1633_r.html (dostęp: 31 V 2016).

Beltrami L., Storia della popolazione di Venezia, Cedam 1950.

Benvenuti G., Storia della repubblica di Genova, Milano 1977.

Blyzniuk S., Famagusta $v 15$ w., „Priczegnomorje v srednije veka” [Sankt-Petersburg] 2000, t. IV, s. 219-295.

Blyzniuk S., Migracija veneceancov na Kipr v XIII-XV vv., „Rosija i Germanija” 2012, nr 2, s. 12-16.

Bostel F., Przyczynki do dziejów złotnictwa lwowskiego, [w:] „Sprawozdania Komisji do Badania Historii Sztuki w Polsce” [Kraków] 1896, t. V, s. 18-19.

Brodel F., Materiana cyvilizacija, ekonomika i kapitalizm, XV-XVIII s., t. I (Struktury povsiakdennosti: mozlyve i nemozlyve), Kyiv.

Brodel F., Sredizemnoje more $i$ sredizemnomorskij mir $v$ epohu Filipa II, Moskva 2002.

Cessi R., La republica di Venezia e il problema Adriatico, Napoli 1953.

Cessi R., Politica ed economica di Venezia nel Trecento, Roma 1952.

Costantini C., La repubblica di Genova, Torino 1988.

Costumes anciens et modernes. Habiti antichi et moderni di tutto il Mondo di Cesare Vecellio précédés d'un essai sur la gravure sur bois par M. Amb, Paris 1859-1860.

Cynarski S., Sarmatyzm - ideologia i styl życia, [w:] Polska XVII wieku. Państwo. Społeczeństwo. Kultura, Warszawa 1969, s. 210-235.

Deluga W., Greek Patronage of the Arts in Lviv in the Sixteenth and Seventeenth Centuries, [w:] Economy and Society in Central and Eastern Europe. Territory, Population, Consumption, eds D. Dumitran, V. Moga, Berlin-Zürich 2013, s. 289-302.

Donaver F., La storia della repubblica di Genova, Genova 1975.

Dudan B., Il dominio veneziano di Levante, Bolonia 1938.

Dumanowski J., Pawlas A., Poznański J., Sekrety kuchmistrzowskie Stanisława Czernieckiego, Warszawa 2012.

Dziubiński A., Na szlakach Orientu - handel między Polska a Imperium Osmańskim w XVI-XVIII wieku, Warszawa 1998.

Epstein S.A., Genoa and the Genoese, 956-1528, London 2002.

Gecsényi L., „Turkish goods” and „Greek merchants” in the Kingdom of Hungary in the $16^{\text {th }}$ and $17^{\text {th }}$ c., "Acta Orientalia Academiae Scientiarum Hungariae" [Budapest] 2007, vol. LX (I), s. 55-71.

Gilles V., Marchands ottomans en Pologne-Lituanie et en Moscovie sous le règne de Soliman le Magnifique, „Cahiers du monde russe: Russie, Empire russe, Union soviétique, États indépendants” 1994, vol. XXXV, no. 4, Octobre-Décembre, s. 713-738.

Grousset R., L'empire de Levant, Paris 1946.

Hernas C., Barok, Warszawa 1973.

Hrusževśkyj M., Istorija Ukrainy-Rusi, t. VI, Kyiv-Lviv 1907. 
Inaldžyk H., Osmańska imperija. Klasyczna doba 1300-1600, Kyiv 1998.

Jakuženko H., Kataloh zbirky zyvopusu Lvivskoho istorycznoho muzeju, Lviv 1987. Jaworski F., Ratusz lwowski, Lwów 1907, s. 44.

Kamianycia Korniakta: Korolivśki zaly: putivnyk Olha Perelyhina, Marija Hul', Myroslav Pobereznyj; LIM, Kyiv 2010.

Karpov S., Putiami srednevekovych morechodov, Moskva 1994.

Katalog dokumentów Archiwum Państwowego w Lublinie, cz. 2 (Katalog Dokumentów różnej proweniencji Miast, wsi, cechów, parafii, klasztorów i osób prywatnych 1397-1794), oprac. M. Trojanowska, Lublin 1998.

Kot S., Polska złotego wieku wobec kultury zachodniej, [w:] Kultura staropolska, Kraków 1932, s. 640-704.

Kretschmayr H., Geschichte von Venedig, Bd. I-II, Gotha 1920.

Ksiega szafarska dworu Jana III Sobieskiego 1695-1696, oprac. J. Dumanowski, M. Próba i Ł. Truściński, red. J. Dumanowski, Warszawa 2013, Monumenta Poloniae Culinaria, t. IV.

Kube A.N., Veneceanskoje steklo, Petrograd 1923.

Kutrzeba S., Handel Krakowa w wiekach średnich na tle stosunków handlowych Polski, „Rozprawy Polskiej Akademii Umiejętności. Wydział Historyczno-Filozoficzny" 1903, t. XLIV.

Laboureur Le J., Relation du voyage de la Reine de Pologne, et du retour de Madame la Mareschalle de Guébriant... par la Hongrie, L'Austriche, Styrie, Carienthie, le Frioul, l'Italie. Avec un discours historique de toutes les villes et Estats per où alle a passé, Paris 1647.

Leicht P.S., Le colonie veneziane, „Rivista di storia del diritio italiano” 1953, vol. XXV, s. 35-59.

Lubomirski J.T., Regestra skarbca ks. Ostrogskich w Dubnie, „Sprawozdania Komisji do Badania Historii Sztuki" [Kraków] 1900, t. VI.

Luzzato G., Studi di storia economica veneziana, Padova 1954.

Lylo I., Narysy z istoriji hrećkoji hromady mista Lvova, Lviv 2002.

Łoziński W., Ormiański epilog lwowskiej sztuki złotniczej, „Sprawozdania Komisji do Badania Historii Sztuki w Polsce" [Kraków] 1901, t. VII, z. 1-2.

Łoziński W., Złotnictwo lwowskie w dawnych wiekach 1384-1640, Lwów 1889.

Łoziński W., Życie Polskie w dawnych wiekach, Kraków1969.

Łoziński W., Życie polskie w dawnych wiekach, Warszawa 2006.

Maciejowski J., Sarmatyzm jako formacja kulturowa, „Teksty” 1974, nr 4, s. 5-26.

Makowski T., Barok, orientalizm i sarmatyzm, „Sprawozdania Polskiej Akademii Umiejętności” 1934, t. XXXIX, nr 8.

Makowski T., Przesławny wjazd Jerzego Ossolińskiego do Rzymu (Najsłynniejsze polskie poselstwo do papieża w 1633 r.), „Spotkania z Zabytkami” 2007, nr 9, s. 9-13.

Makowski T., Z dziejów stosunków państwa i Kościoła. Polskie poselstwa obediencyjne w XVI i XVII wieku, „Teologia Polityczna” 2003-2004 [Warszawa 2004], nr 1 , s. 201-211. 
Małowist M., Wschód a Zachód Europy w XIII-XVI wieku. Konfrontacje struktur społeczno-gospodarczych, Warszawa 1973.

Mańkowski T., Genealogia sarmatyzmu, Warszawa 1946.

Mańkowski T., Orient $w$ polskiej kulturze artystycznej, Wrocław-Warszawa-Kraków 1959, „Studia z Historii Sztuki”, t. VIII.

Mańkowski T., Polskie tkaniny i hafty XVI-XVII w., Wrocław 1954, „Studia z Dziejów Polskiego Rzemiosła Artystycznego".

Mańkowski T., Sztuka islamu w Polsce w XVII i XVIII wieku, Kraków 1935.

Mańkowski T., Zachód $i$ Wschód $w$ tkactwie polskim XVII wieku (tkacze Koniecpolskich), Kraków 1932.

Mańkowski T., Ze studiów nad dawnym tkactwem Polskim. Z powodu wystawy w instytucie propagandy sztuki, „Nike” 1938, R. II, z. 2.

Martin Gruneveg (otec Venčeslav): duchounik Mariny Mniszek. Zapiski o torgovoj pojezdke v Moskvu v 1584-1585 g, sostavitel A.L. Horoszkevicz, Moskva 2013.

Nadel-Golobic E., Armenians and Jews in Medieval Lvov: Their role in Orient trade, "Cahiers de Monde Russe et Sovietique” [Paris-Hague-New York] 1979, vol. XX, nos. 3-4, s. 345-388.

Norwich J.J., A history of Venice, London 1982.

Ovsińskyj J., Filvarkove hospodarstvo Reči Pospolytoji XVIII s. v ocinci polskoji istoriografiji, Lviv 2005, Problemy slovjanoznavstva, vyp. 55, s. 29-40.

Ovsińskyj J., Majetkovyj kompleks Zevuśkych na Podilli u XVIII s., [w:] Folwark, wieś, latyfundium. Gospodarstwo wiejskie w Rzeczypospolitej XVI-XVIII wieku, red. J. Muszyńska, S. Kazusek, J. Pielas, Kielce 2009, s. 125-137.

Ovsińskyj J., Podilskyj filvarok u 20-30 rokach XVIII s.: osnovni typy ta struktura (na prykladi majetkiv Zevuśkych), Cerkasy 2008, Ukraińskyj selianyn. Zb. Naukovych Prać, vyp. 11, s. 135-145.

Reychman J., Orient w kulturze polskiego Oświecenia, Wrocław 1964.

Rybarski R., Handel i polityka handlowa Polski w XVI stuleciu, t. II, Poznań 1929.

Samsonowicz H., Miejsce Polski w Europie, Warszawa 1995.

Samsonowicz H., Złota jesień polskiego średniowiecza, Poznań 2001.

Sokolov N., Obrazovanije Venecianskoj kolonialnoj imperiji, Saratov 1963.

Sribnyj F., Studiji nad orhanizacijeju Lvivskoji Stavropihiji vid kińća XVI do perszoji polovyny XVII s., Zapysky NTŠ, Lviv, t. CVIII.

Talbierska J., J. Stefano Della Bella - Etchings from the Collection of the Print Room of the Warsaw University Library, Varsavia 2001.

Tatanajeva L.I., Sarmatkij portret. Iz istorii polskogo portreta epoki barokko, Moskva 1979.

Tazbir J., Rzeczpospolita i świat. Studia z dziejów kultury XVII wieku, Warszawa 1971.

Venclova T., Mit o początku, „Teksty” 1974, nr 4, s. 102-113.

Vojtovych L., Formuvannia krymskotatarskoho narodu. Vstup do etnohenezu, Bila Cerkva 2009, s. 150-157. 
Vojtovych L., Lev Danylovycz, kniaz halycko-volynskyj (bl. 1225-bl. 1301), Lviv 2014.

Vojtovych L., Torhivlia $i$ torhovelni szlahu, [w:] Istorija ukrainskoji kultury, t. II (Ukrainska kultura XIII - persza polovyna XVII s.), Kyiv 2001, s. 81-93.

Wyczański A., Polska-Rzecza Pospolita Szlachecka 1454-1764, Warszawa 1965.

Zakrzewska-Dubasowa M., Ormianie zamojscy $i$ ich rola $w$ wymianie handlowej i kulturalnej między Polska a Wschodem, Lublin 1965.

Żukowski J., W kapeluszu $i w$ delii, czyli ewenement stroju mieszanego $w$ dawnej Rzeczypospolitej, „Kwartalnik Historii Kultury Materialnej” 2009, nr 1, s. $19-37$. 